\title{
Cultural Heritage Tourism Potential at Six former American Board Mission Stations
}

\author{
Gordon Fakude \\ University of KwaZulu-Natal
}

\begin{abstract}
This initial assessment of the cultural heritage tourism potential is a component of a broader project aimed at conducting research and revitalizing selected former American Zulu Mission Stations in southern parts of KwaZulu-Natal. Whilst the Heritage, Tourism and Community Development Project is being considered by a range of stakeholders including local communities at the localities where the six mission stations are located, the University of KwaZulu-Natal is charged with leading the research component of the project. The purpose of research in this project is to 'lay bare' the indelible print on the cultural and heritage landscape left behind by the missionaries in this region of South Africa. A principal component of the project is to encourage community development through promotion of religious heritage tourism in order to stimulate local tourism-based production and services such as crafts, hospitality accommodation and cultural/educational events in the Mission Stations. Therefore, the purpose of this part of the research is to present an initial scan of the heritage tourism potential of the six mission stations.

\section{Missionary heritage: an undocumented component of the cultural and heritage landscape of KwaZulu-Natal}

The presence of missionaries of various denominations left an indelible print on the cultural and heritage landscape of the KwaZulu-Natal region of South Africa. Scholars agree that KwaZuluNatal, more than anywhere else in the world, received the lion's share of missionary activities in the nineteenth centuries. Although many mission stations lost their vibrancy and gradually declined following the transfer of the education function to the government during the apartheid era, mission stations continued to be focal points of social transformation (especially in the countryside) and the legacy of missionary work can be seen today.

Unfortunately, much of the missionary heritage referred to above is not documented to preserve it for future generations. Nor is this heritage currently being tapped into to stimulate or enhance cultural/heritage tourism in these areas. Therefore, the intention of this project is to explore the potential of former Mission Stations as cultural heritage sites and investigate ways of boosting local socio-economic development in these areas by linking the rehabilitated mission stations as heritage to established tourist attraction nodes and themed routes.

\section{Cultural Heritage Tourism}

\section{Definitions}

Culture is conventionally defined in terms of shared norms, values, customs and artistic achievements held by a group of people at a certain time, whilst heritage is defined in terms of 
what is inherited by one generation from past generations. ${ }^{1}$ What these two definitions indicate is that the combination of heritage and culture leads to considerations of human activity related to, and including, the built/human-made environment (monuments, buildings and artefacts) and the natural environment (mountains, lakes, rivers)

Cultural heritage tourism, on the other hand, is defined as travel directed towards experiencing the arts, heritage and special character of a place. ${ }^{2}$ Cultural heritage tourism is important for various reasons:

$>$ It has a positive economic and social impact.

$>$ It establishes and reinforces identity.

$>$ And, it helps preserve local cultural heritage.

With culture as an instrument, cultural tourism facilitates harmony and understanding among people and it supports culture and helps renew tourism. Cultural and heritage tourism projects are normally established in response to questions such as: how can history, culture and natural beauty be packaged in a way that attracts visitors but also respects communities' special places? As well as, how can tourism be used to help boost rural economies? Discuss the broader implication of these questions

\section{Current international trends}

Heritage and culture have been long-standing elements of tourism. In recent years entrepreneurs 'rediscovered' heritage and culture as important marketing tools to attract tourists with special interests in the arts. Tourism experts and commentators note that cultural heritage tourism is the fastest growing segment of the tourism industry because there is a trend toward an increased specialization among tourists. This is evident in the evolving tourism trends which point to a shift away from mass tourism to more individualistic patterns as tourists seek greater flexibility and a more meaningful experience. This trend is demonstrated by the increased volume of tourists seeking adventure, culture, history, archaeology and interaction with local people.

\section{Current trends in South Africa}

A recent study conducted by South Africa Tourism (SAT), a parastatal agency charged with promoting tourism from foreign countries into South Africa, indicated that while cultural/heritage products are highly desired by tourists, they are currently underperforming in South Africa. ${ }^{3}$ SAT's gap analysis showed that more tourists expressed a desire for cultural and historical heritage than wildlife viewing, but few had experienced it while in South Africa. ${ }^{4}$ The study therefore concluded that South Africa's cultural/heritage tourism product is one of the country's key attractions and needs development. There is a great need for cultural heritage tourism to take advantage of this economic potential. Tourism companies can work with local communities to see how opportunities stemming from South Africa's cultural diversity can be unlocked. Therefore, this initial scan of the tourism potential of the six areas aims to explore this

\footnotetext{
${ }^{1}$ R. George, Managing Tourism in South Africa (Oxford University Press, 2007).

${ }^{2}$ M. Thompson, Cultural Tourism, Washington Heritage Bulletin, vol. 20. No. 4 (Summer 1998).

${ }^{3}$ South African Tourism, Domestic Tourism Growth Strategy (2003), See http://www.info.gov.za/otherdocs/2004/growthstra.pdf

${ }^{4}$ South African Tourism, Domestic Tourism Growth Strategy (2003).
} 
potential for tourism growth in rural/peri-urban areas. Before we discuss each of these areas' potential for tourism development, let us first contextualise the product development strategy currently .being pursued by the tourism authorities.

\section{The KwaZulu-Natal Tourism Product Development Strategy}

The Deloitte \& Touche Consortium conducted research for the preparation of the Tourism Product Development Strategy. The following two findings inform the strategies that were adopted:

(i) The largest sectors of both domestic and foreign tourist-source markets are seeking a coastal destination for their leisure holidays; and

(ii) The two main disappointments for departing foreign tourists was their lack of ability to interact with traditional culture and heritage, as well as wildlife. ${ }^{5}$

These findings in turn led to the recommendation by the Tourism Working Group that a focus be given to developing:

(1) A primary tourism product development strategy for KwaZulu-Natal that would aim to build a reputation for its coastal destinations;

(2) A parallel tourism product development strategy for the establishment of a Zulu Heritage and Cultural Trail. This trail would provide the enabling environment for broadening of ownership within the tourism sector, particularly within the rural and previously disadvantaged sectors, and compliment and improve the existing product mix within the context of the 'Kingdom of the Zulu' branding;

(3) Policies for strategic intervention for inclusion of a 'Zuluness' within other tourism product development initiatives particularly within the destinations of Durban, Pietermaritzburg / Midlands Tourism Corridor and the uKhahlamba-Drankensberg World Heritage Site.

The Tourism Product Development Strategy identified the need to focus on coastal destination product development and marketing in order to widen access into relatively untapped foreign tourist-source markets as well as domestic tourists who also seek coastal destinations. In addition, the Strategy acknowledges that tourists need to be offered unique additional activities associated with wildlife, heritage and culture viewed within the African context. The creation of the Zulu Heritage and Cultural Trail has been identified as the key attraction to draw tourists into rural areas and is considered as the 'glue' that will join together the wide diversity of rural cultural tourism attractions and sites of historical importance. The sustainability of the proposed strategy for the development of tourism within rural areas should be based on the need to ensure growth of tourist numbers and tourism revenue into KwaZulu-Natal.

The Strategy's findings pertaining to Durban and the South Coast regions are crucial to the initial

\footnotetext{
${ }^{5}$ South African Tourism, Domestic Tourism Growth Strategy (2003).
} 
scan of the tourism potential of the American Zulu mission stations. A majority of the mission stations are located within the South Coast region, while some lie in close proximity to Durban. Heritage, culture and wildlife are identified by the Strategy as sectors that are 'next highest on the visitors' list of things they want to do when they visit KwaZulu-Natal. An opportunity exists to provide heritage, culture and wildlife attractions for the majority of Durban's tourists, who for reasons of time and/or cost usually cannot travel northwards to enjoy the game reserves and Zululand areas.

With regard to the South Coast, the Strategy proposed that the region be maintained primarily as a domestic tourism destination, due to the affordability of the existing products. Further, the Strategy highlighted that potential exists inland to develop adventure, eco and cultural tourism products that would add value to the coastal destinations (of the South Coast) and provide a differentiation with other destinations in KwaZulu-Natal and elsewhere. With regard to the need to open up 'inland tourism' into the rural areas of the South Coast hinterland, the Strategy's recommendation is to develop some form of collective framework whereby the variety of individual projects focusing on culture, heritage and wildlife and the scenic beauty of the area are brought together with the objective of creating a single inland destination image.

\section{Heritage tourism potential of the six former American Zulu Mission Stations}

The six former American Zulu mission stations visited in the course of undertaking research were all established in the mid nineteenth century. Adams Mission Station is the oldest and was built in the late 1830s by the first group of American missionaries. Five of the original church buildings still stand and are being used for church services, whilst one at Amahlongwa Mission Station has been pulled down and replaced with a modern face-brick church building. Mission stations visited and whose cultural heritage tourism potential were scanned are:

- Imfume

- Amahlongwa

- Mthwalume

- Adams

- Ifafa

- Mzumbe

Whilst the possibility of rehabilitating old buildings and preserving them as heritage sites exists in all sites visited, their potential to attract visitors varies depending on a number of factors that determine success for establishing such tourist ventures (such as access and proximity to established tourist attractions) as shown in the brief sections depicting impressions of visits to each mission station below.

\section{Imfume ${ }^{6}$ Mission Station}

The mission station was built in 1860 with the original church building still being used to conduct church services. Several original buildings can be renovated to preserve the unique architectural history and serve as tourist attractions. Easy access to the mission station is

${ }^{6}$ name origin = Ifa Ume (IsiZulu for "die on your feet"). 
provided by a $10 \mathrm{~km}$ tar road which is in relatively good condition and is linked to the N2 highway on the coast.

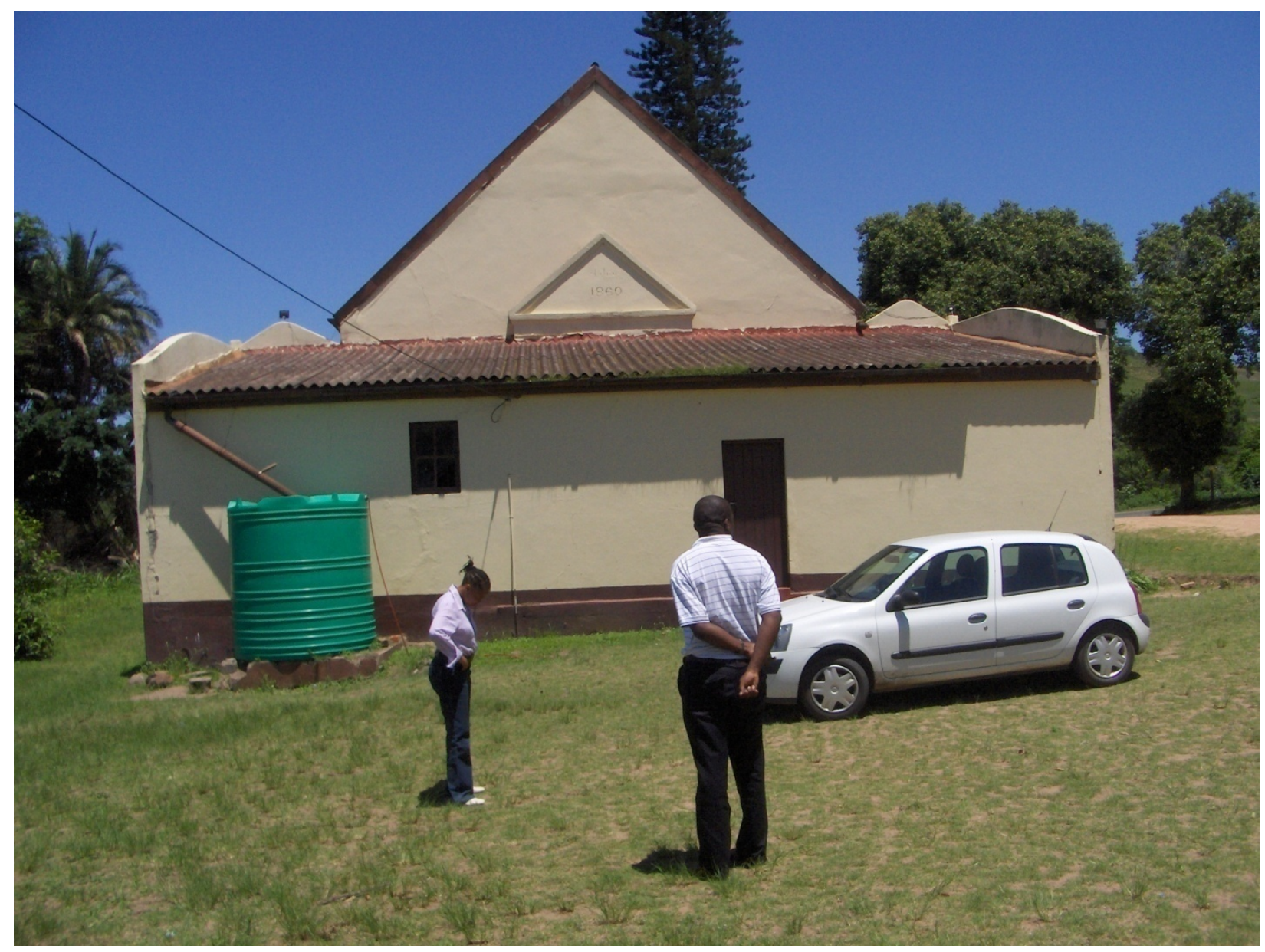

Figure 1: Picture of the original church building still in use at Imfume Mission Station

There are many prominent individuals in the country's socio-political landscape that came from Imfume and who were educated at the mission station. One of the homesteads visited is the Mali homestead. The homestead gave birth to the late Minister of Health, Manto Shabalala Msimang. During the team's visit to Mali homestead we met Msimang's sister, who is a school principal and a local ANC councillor. She related many stories that can serve to create story-legends and reinforce attractions to the area such as how the place acquired its name during Shaka's reign. One such story she told was of how the first American Board missionaries acquired the land on which they built the mission station with full support of the local chief and his council.

In terms of the natural landscape, Imfume is blessed with beautiful scenery of a lush and hilly countryside, typical of the hinterland of the South Coast. Potential exists for eco and adventure tourist ventures e.g. $4 \times 4$ tracks in the hilly countryside which can be an immediate boost to tourism with domestic or tourists from the SADC region. Potential also exists for agri-tourism as the area looks good for agricultural development which is still minimal at present. Imfume is adjacent to several towns such as Umkhomazi, Scottburgh and Umzinto. All have significant tourist facilities and are popular with South African tourists. 


\section{Amahlongwa Mission Station}

The Amahlongwa mission station's original church building no longer exists. Instead, there is a modern (face-brick) church building where church services are conducted. The area has good scenery that is enhanced by a magnificent view of the sea. This proximity to the warm Indian Ocean is an advantage in terms of tourism development.

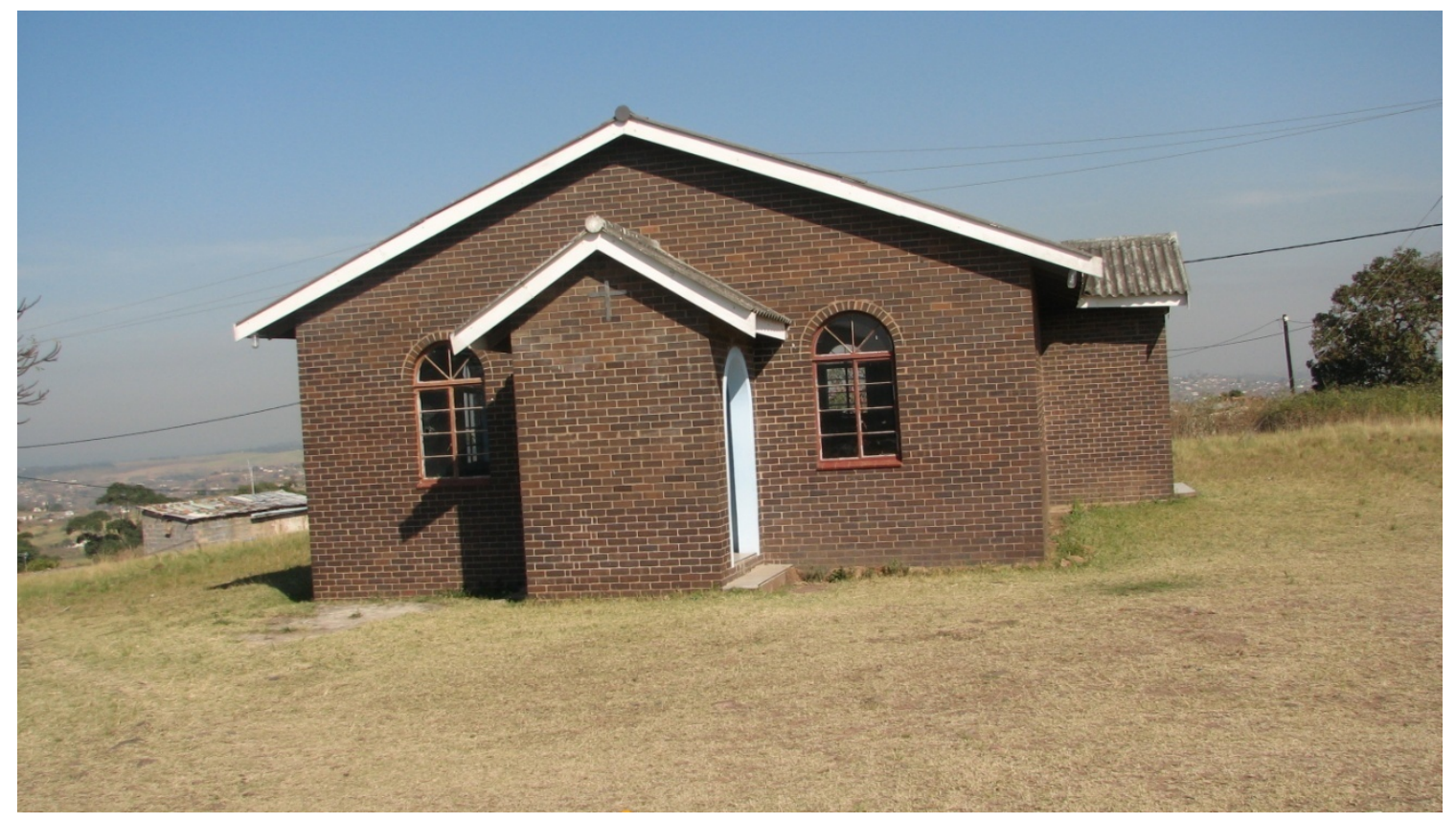

Figure 2: Picture of the modern church building

The Amahlongwa community built the church without outside funding. Not only was it built by local money, but the builder is a well known member of the UCCSA local church. Mr. Ngidi takes pride in his contribution to the church. In an interview with the Mission Stations Team he mentioned that he did not charge the church a penny for his labour of love that, at the time, he spent picking and laying each and every brick for the church building, was his thanksgiving offering to God for saving his life in a car accident. This local initiative demonstrates that people value the church and are keen to maintain it.

A thriving commercial agriculture also (sugar cane farming) exists. Beautiful homesteads add to the beauty of the scenery. The area is also in the world literary map having produced a prominent philosopher and epic poet, Mazisi Kunene (1930-2006, see Introduction to this volume) whose grave lies a few kilometres away from the church. There is thus a potential to link the area to literary tourism routes as Mazisi Kunene was a world renowned poet laureate.

Amahlongwa's potential for heritage tourism development is dependent upon it being a part of a tourism route. The area has good roads (tarred roads) and its proximity to the N2 is an advantage. 


\section{Umthwalumi Mission Station}

Umthwalumi Mission Station is also a century old institution. The original church building is used as efforts to build a new church did not go beyond the laying of foundation. No one is staying in the premises currently. The premises are near the local store, government clinic and Umthwalumi High School. The store is also used as a pension pay-out point and is thus a centre for economic activities at least once a month. There is also a taxi rank nearby.

Umthwalumi is marked by beautiful scenery typical of the southern parts of KwaZulu-Natal. The mission station is easily accessible to the N2 highway. The area lies in close proximity to the coastal tourist attractions to which it is linked through a gravel road that meanders through the terrain alongside the Umthwalumi River. Driving along this river's beautiful meanders surely raises the adrenalin and would be thrilling especially for the adventure-seeking tourist segment.

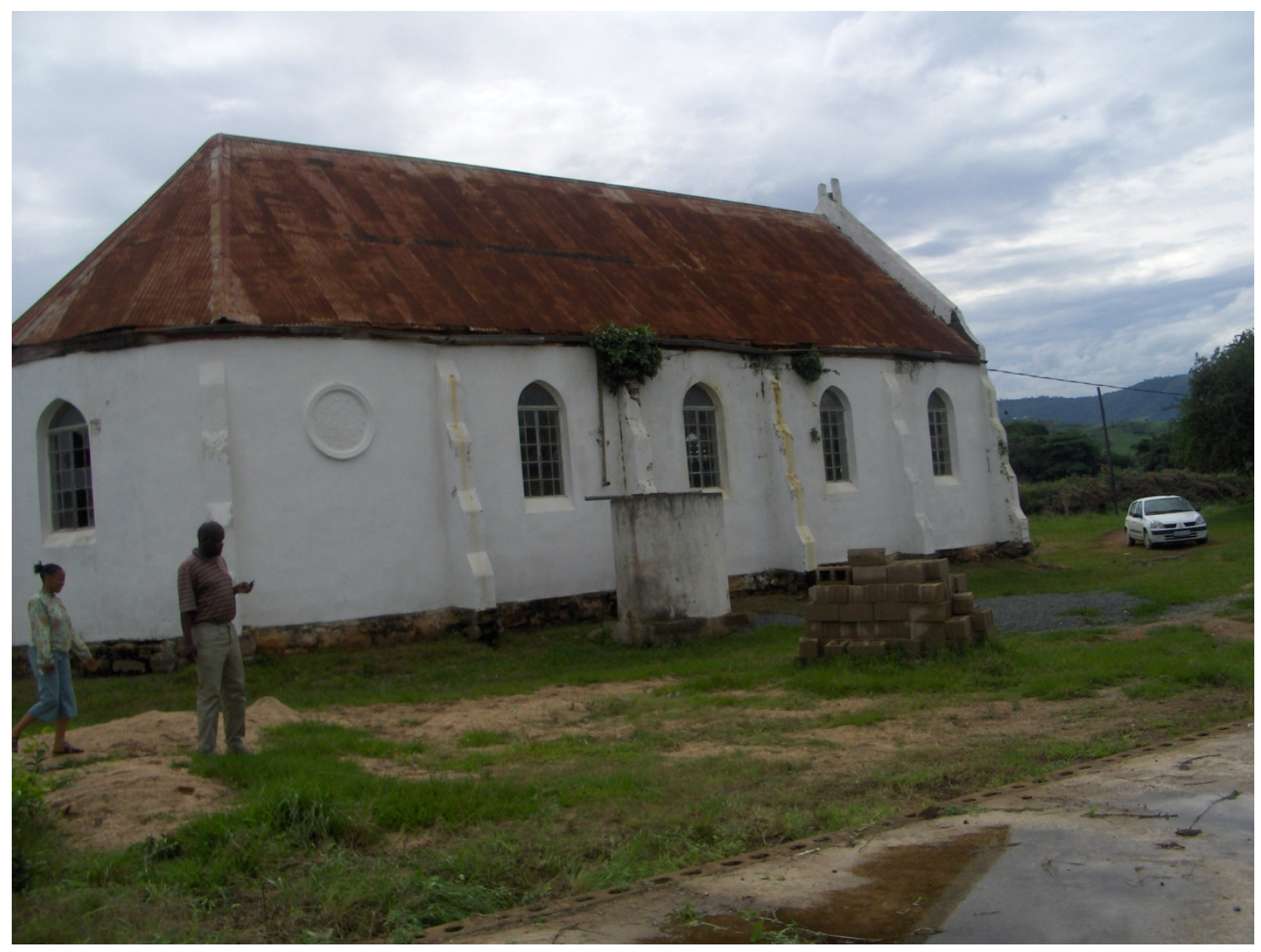

Figure 3: Picture of the church, Nokuthula Cele (from left) and Thulasizwe Makhanya

Umthwalumi River valley where the mission is located has potential for agricultural production, though it is still not exploited. This potential (especially vegetables and fruit production) can be used to reinforce tourism development through agri-tourism and contribute to local economic development.

\section{Adams Mission Station}

The original church building has been rehabilitated (through contributions solicited from the 
private sector such as Harmony Gold Company and Nelson Mandela). Adams Mission Station has the best prospects for success as a tourist attraction (of all the mission stations visited) as it has a rich history and can be easily linked to major heritage routes and mass tourism attractions such as Durban and Amanzimtoti beaches nearby.

The Adams College itself is a certain draw card for tourism development owing to its particular history as it has been the leading institution where many African leaders and intelligentsia were educated. Thus there is a need to link with established heritage routes, (e.g. Inanda/ Ohlange route) to learn from their experience and explore potential linkages. Evidence of community participation and mobilisation bodes well, though the project should be cautious and aware of 'sharks' who only want to enhance their self-image and benefit as individuals. In contrast, individuals, such as Mr. Makhanya, are knowledgeable about the area's history and are keen to see the project take-off. Such individuals should be drawn in and their knowledge utilised for the advancement of the project.

There are several old buildings (linked to the mission station's history) that can be renovated, such as the building where Chief Albert Luthuli and other prominent historical figures used to stay when teaching at Adams College. One old building has the potential to be turned into a museum. For the prospect to be successful a focus on collating and documenting the history of the mission station is necessary. Much goodwill towards the project currently exists in government which should be employed to make the project a success. Consequently, prospects for a heritage tourism project are most promising at Adams Mission Station.

\section{Umzumbe Mission Station}

The mission station was built in 1862 by the American Board missionaries (Rev. Abrahams Cowley notable amongst them) and is one of the earliest American Board mission stations in Natal. A double-storey building, which was the first original building of the mission station, still stands and can be renovated as a heritage site. The building housed the first Girl's Seminary commonly known as Umzumbe Home. Later, the school closed after the establishment of Inanda Seminary, near Durban, where many African women leaders like former minister of Defence, Mrs Nozizwe Madlala-Routledge in government and the private sector were educated.

There exists potential for a heritage site given the beautiful scenery and history. However, access to the area and site is difficult because of the poor gravel/dirt road which makes the $14 \mathrm{kms}$ from the N2 highway to the site unpleasant. The journey can take up to 30 minutes due to the perilous state of the pot-holed road. 


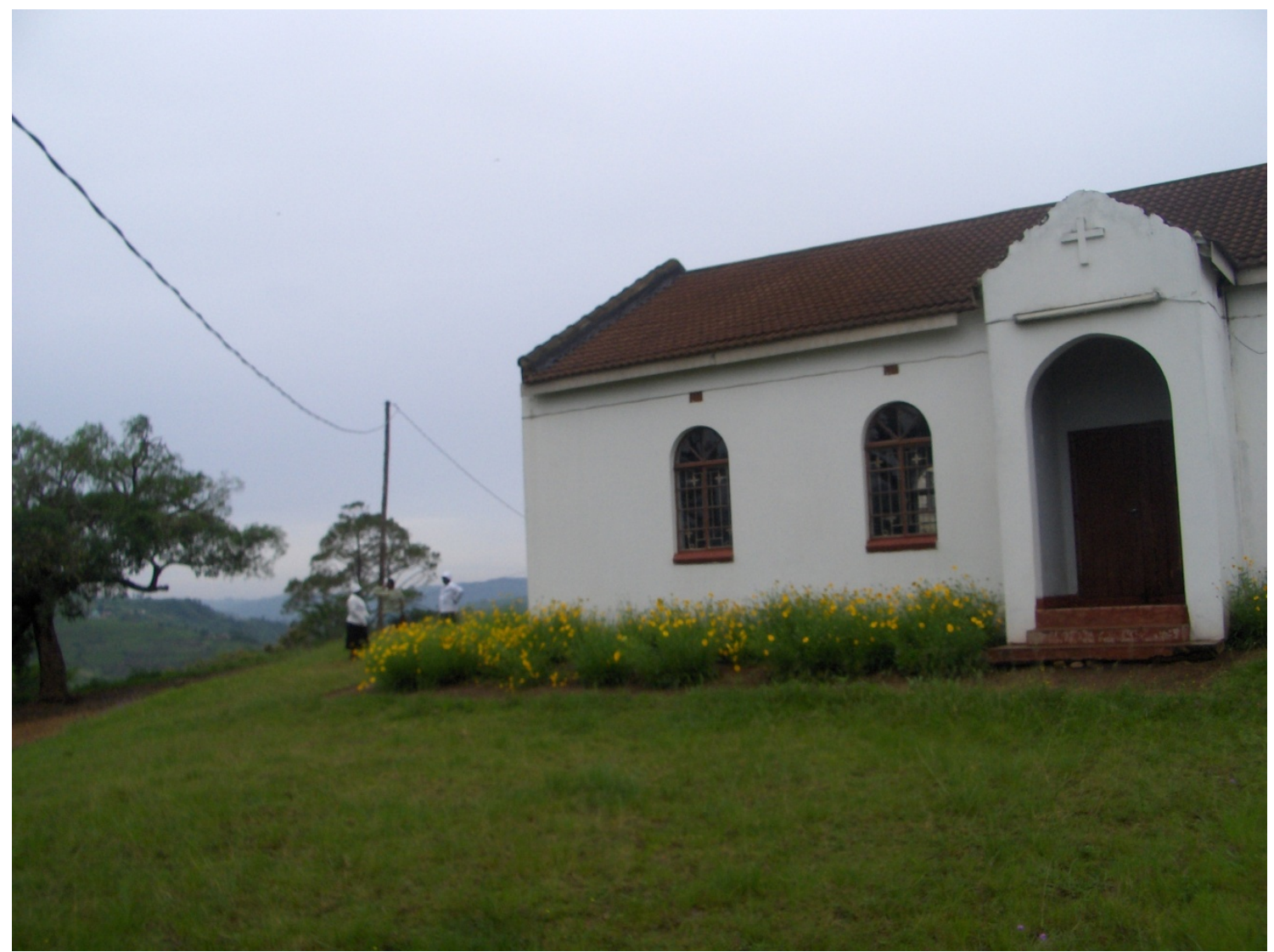

Figure 4: Umzumbe Church

Umzumbe's proximity to the sea, especially the Hibiscus Coast beaches and tourism nodes such as Hibberdene, Mtentweni, Shelly Beach and Port Shepstone stands it in good stead in terms of tourism development especially if heritage/cultural products are to be developed to complement the coastal beach attractions. The landscape offers beautiful scenery en route to the site, which helps meet a key requirement for successful development of tourism routes: to ensure that tourists are not bored during the trip to the site. 


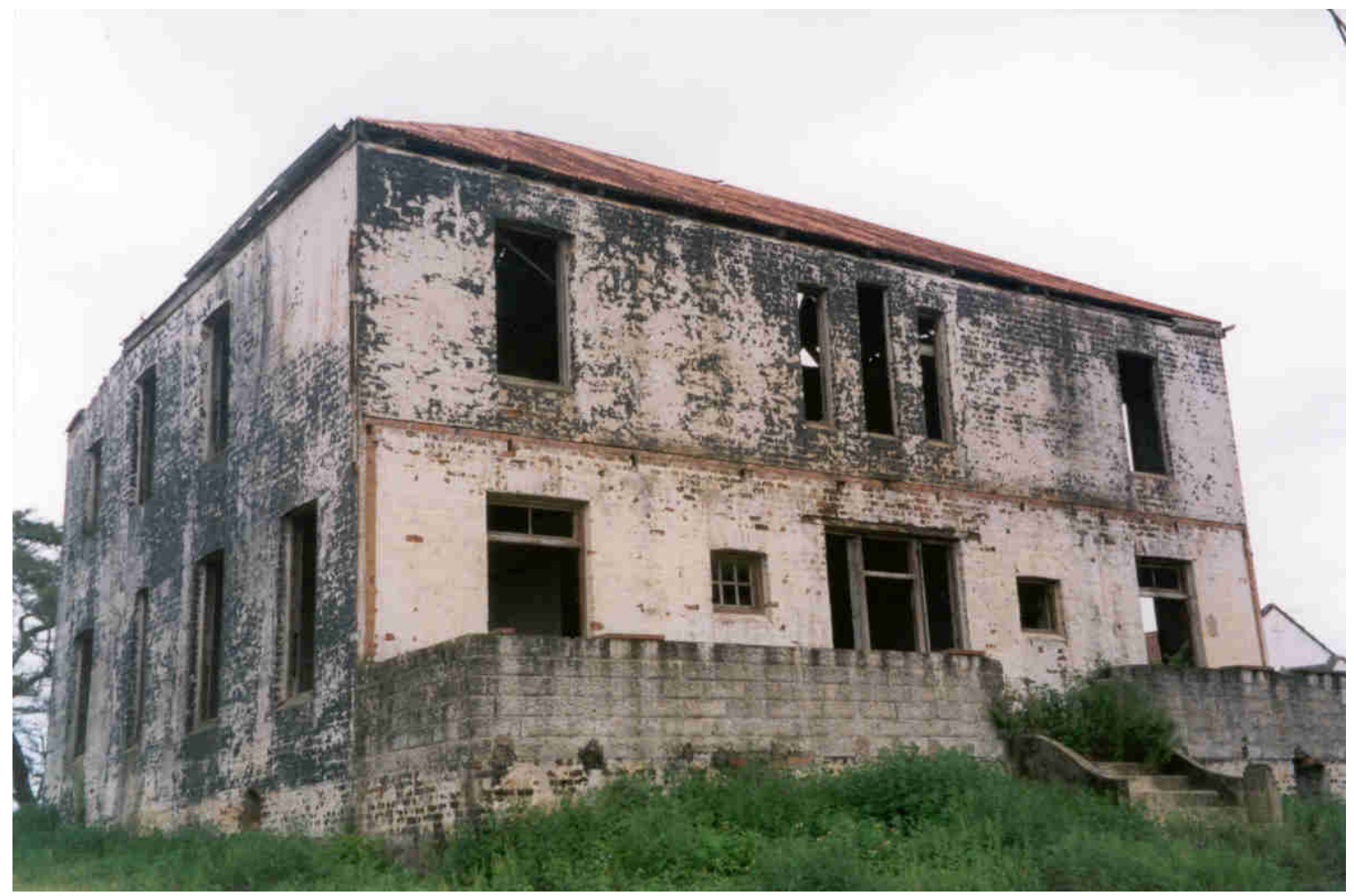

Figure 5: Double Storey original structure, built in the 1860s

Development of the site will do well especially if it is linked to agricultural development. There is an agricultural project nearby that is aimed at boosting household banana production by reviving an irrigation scheme that was started or put in place by the American missionaries decades ago. Nearby at Morrison's Post, the provincial Department of Agriculture helped set up community stalls to market agricultural produce, which is a necessary step to build on in developing links between the proposed heritage tourism and agri-tourism. This can be developed when the agricultural development project is in full swing. A further positive attribute of the proposed site is that the banana agricultural development project and the old mission church and farm retail outlets lie within a $2 \mathrm{~km}$ radius of each other.

A need exists to mobilize or galvanize both the local and district municipalities to source funds to improve the gravel road to the site area as the proposed tourism development can only be realized and become successful if there is better access through improved roads to the area. Access is crucial for the economic viability of the proposed tourism development project.

The mission station is built on a beautiful site with good views of the surroundings particularly the nearby meandering Umzumbe river and the good agricultural land for the proposed banana project. The site is not isolated as it is surrounded by a primary school to the east and the current church to the west. It is therefore situated in a place that has a lot of movement and activities.

A supplementary need exists to identify prominent individuals in the Umzumbe history who are linked to the area's development to enhance the proposed heritage project. The site stands next to the famous former national Deputy Minister of Healty Nozizwe Madlala's homestead; this can be explored to see what advantage it can bring to the proposed development. Bridget Portmann 
has also done research on Nomabhodwe Madlala, on of the first students at Umzumbe in the 1860's. Madlala later worked with the community of KwaDweshula 20km from Umzumbe to build a school and church.

A preliminary conclusion is that potential exists for tourism development in Umzumbe. However, improved access is needed as the road is currently a major stumbling block to people wishing to visit the site and a disincentive to the realization of the idea of integrating heritage/ cultural tourism and economic and agricultural development in the area.

\section{Ifafa Mission Station}

Built in the 1870s, Ifafa Mission Station is located close to tourism towns such as Pennington, Ifafa, Kelso, Sezela, Bazely Beach, Elysium and Umthwalumi - all are popular resorts in the area. A number of RDP houses built in recent years on land surrounding the mission station give an image of a mission station located in a township. This can be explored to establish any potential for organizing township tours that are linked to the mission station. Furthermore, there is potential for organizing farm tours (agri-tourism) as there are many different crops that are grown in this area (banana, sugar-cane, pineapples, macadamia nuts, pecan nuts, etc.) whilst further inland South Africa's national flower, the Protea, is farmed.

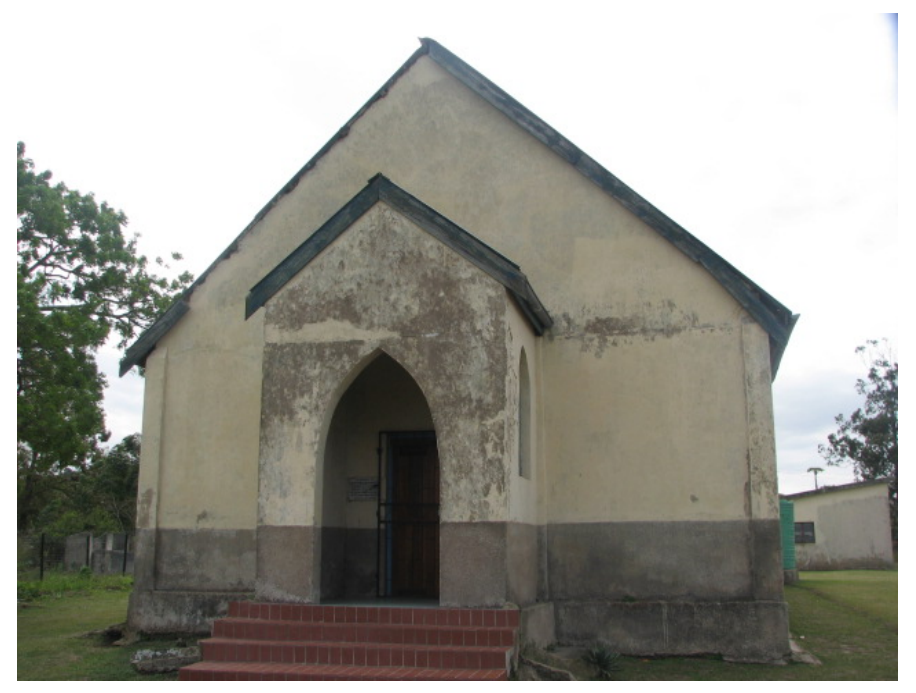

Figure 6: Church building at Ifafa

The old buildings next to the church were used by former missionaries can be restored or renovated to preserve and enhance the heritage of the area. There appears to be little potential for tourism development for the mission station on its own. However, the mission station's potential can be realized by exploring possible links (such as agri-tourism and cultural township tours suggested above) with either established tourism routes or with sister mission stations such Adams and Imfume who are more viable.

\section{Looking to the future}

A key implication emerging from this preliminary scan of the tourism potential of the six mission stations is that if these areas are viewed in the context of the existing tourism attractions 
of the South Coast, the potential for tourism development can be realised. It should be pointed out, however, that for most of them there is very little potential for attracting tourists if they developed as stand-alone projects. So, there is a need to explore the possibility of 'themed routes' that incorporate several attractions. Most areas do not have the potential to independently entice visitors to spend time and money. By combining the attractions into regional packages, that in the context of the South Coast will involve exploiting the un- or under-explored cultural heritage of the hinterland areas, the tourism potential of these areas can be realised. Much needs to be done to provide the necessary infrastructure (such as roads and improved sanitation) and facilities for tourists in some of these areas.

As a way forward, this study proposes that any tourism development strategy should undertake the recommended key steps in establishing heritage trails:

- Step 1: Establish partnerships to create a Heritage Trail. This will involve identifying core partners and engaging a stakeholder. Partnerships that utilize the vast experiences of established tourism businesses will ensure the commercial viability of any proposed ventures.

- Step 2: With partner organisations identify the trails in the geographic area. Clarify the products to be included in such a trial and how they will be linked to create a heritage trail. The following questions need to be answered:

$>$ What form of transport should be used?

$>$ What is 'unique' about the trail?

$>$ And, what the trail has to offer?

- Step 3: Train stakeholders and partner organisations to conduct a market analysis. This will also entail developing a marketing strategy that considers demand with tourism producer capacity, ensuring that heritage trail sign-posts are in place on the trail and existing on maps, and also deciding on the price that the tour-operators will charge for the tours including transport to the destinations.

Step 4: Market the heritage trail by preparing and distributing advertising materials to identify potential customers.

As seen in the above steps, an essential element of setting up such themed routes is cooperation as opposed to competition between the variety of attractions and tourism suppliers. In the tourism industry it has been demonstrated that alliances offer better opportunities to market a product far more widely. This is very critical especially when new products such as the proposed tourism development in these areas are pursued.

Another key element that is crucial in the development of the proposed heritage trail will be the involvement of the state (both local and other levels) particularly in terms of providing the necessary infrastructure. Tourism bodies in the province identified the gap of cultural heritage attractions in the current supply of tourism products. Therefore, the state (especially 
at local government level) should be pro-active and seek ways to build on this potential tourism in their areas.

\section{Conclusion}

The main purpose of the research on the cultural heritage tourism potential of the six former American Board missionary stations in the South Coast of KwaZulu-Natal was to explore potential to promote religious heritage tourism in this region of KwaZulu-Natal with a view to stimulate local tourism-based production and services in order to encourage community development. As demonstrated above, potential exists for the development of this type of tourism. This exploration found that such potential can be realized not as stand-alone projects but only if they are integrated into the existing circuits of tourism attractions which have proved to be sustainable. 
